\title{
Language Therapy Model for Treating Adult Aphasic Patient
}

\author{
Gusdi Sastra ${ }^{1}$, Ike Revita ${ }^{2}$ Handoko $^{3}$, Hendra Permana ${ }^{4}$ \\ sastrabudaya84@gmail.com ${ }^{1}$, revita_ike@yahoo.com ${ }^{2}$, \\ handoko@hum.unand.ac.id ${ }^{3}$,ehen_exel@rocketmail.com ${ }^{4}$ \\ Faculty of Humanities, Universitas Andalas, Padang, Indonesia ${ }^{1,2,3}$, Faculty of Medicine, Universitas \\ Andalas, Padang, Indonesia ${ }^{4}$
}

\begin{abstract}
Language disorder is one of communication impairment which can be treated by using language therapy. The research aims to formulate therapy based on a linguistic approach which can be applied to the patient of language disorder. The method used is a behavioral therapy method which is one of language therapy (logopedia) method that can be applied to improve communication skill for an adult who has an expressive and receptive impairment. The model is designed to improve linguistic behaviour for an adult with expressive and receptive aphasia by focusing on functional communication. The results show that aphasic patients are significant improvement of phonological and lexical accuracy. In the last mouth of the third-mount stage of speech therapy, the intended meaning can be identified by the patient based on the speech act. The progress indicates the improvement of the patient's skill in communication. Almost $87 \%$ of 50 speech situations used in the test shows improvement in pronunciation and word accuracy. The result is based on the numbers of phonological, lexical, and semantic error during the application of behaviour therapy model. Furthermore, it is also supported by the normal direction of speaking and phonological accuracy which can be inferred from stimulus trial and speech analyzer of the patients.
\end{abstract}

Keywords: Aphasia, Behavior Therapy Model, Stimulus, Communication, And Speech Analyzer.

\section{Introduction}

In communication, human beings deal with the aspect of verbal and nonverbal. Verbal language is the language used to express ideas orally or by using the utterances and writing, while nonverbal language takes other forms besides oral or written which is then known as a sign or gesture language. In daily communication, people dominantly use verbal communication rather than nonverbal one. It mentions in the research conducted by linguists and psychiatrist in America which show that the use of verbal language is more dominant than nonverbal communication.

In using verbal communication, every human is equipped with the ability to speak. However, it is different for each, some individuals are normal, but some others may have a problem with verbal communication. In term of normal communication, the speaker has certain abilities to perform linguistic rules, such as stress, intonation, language structure and others. On the other hand, abnormality in speaking deals with the disability in speaking according to the 
linguistic rules and context of normal speaking which distracts people from reaching the target of expected communication.

People with speech impairment are easy to identify in society. It can be caused by factors, such as impairment on language nerves function in the brain, the distracting of the articulator, or mental pressure must have been the causes. Several people lose their ability to express their ideas through utterances which are called cortical motoric aphasia [1]. They have been able to comprehend oral and written language but unable to figure out the verbal expression, but some may understand nonverbal expressions.

Disorder in verbal expression frequently found in society occurs among stroke patients. Stroke is caused by the distraction of blood circulation on the brain which usually occurs toward people over 40 years old. Beside motoric dysfunction, a stroke often causes language impairment [1],[2]. Stroke in left hemisphere affects language ability which distracts the patients to perform verbal expression or nonverbal. For communication purpose, the patient usually uses a nonverbal expression by performing a gesture of part of the body even almost half of his body is weak. Moreover, the stroke patients are more capable of understanding the utterances of other people when speakers use both verbal expression and nonverbal expression.

In medical science, language disorder is referred to as aphasia which is firstly introduced by Th. Alajuoanine, A. Ombredane, and Marguerite Durand [3]. Their research is concerned about the simplification of sound pattern in the aphasic patient. Through now, researchers continue to conduct on the human brain in relation to language ability of the aphasic patient and other disorder. In Indonesia, Sastra, et al. [4] had researched aphasic patient by focusing on developing Language Therapy Model (LTM) to increase the communication ability of the aphasic patient. The model has been applied to the adult aphasia patient in an adult.

The related theory of the research is based on the approach and strategy, DharmaperwiraPrins [5] who concerned about the model of analyzing language information processing in brains. The model is both sophisticated and relevant to reach the objective of the research. According to Prins, the analysis of language processing in the brain not only needs linguistic forms as the basis of analysis but also a model of information analysis. Pris explains that inputs, i.e. auditory, visual, and tactical, will be analyzed firstly on the brains. These stimuli will affect one another. Therefore, some aspects, such as attention, memory, emotion, and feeling become the key factors in designing the linguistic therapy for the patient with language disorder.

The therapy model proposed by Dharmaperwira- Prins [5] consists of several steps. The input of information is sensed by auditory, visual, tactical equipment which will be passed to the posterior area of the brain. The information is evaluated in the limbic system by considering emotional of personal relevance. Selective attention drives to the current information based on personal relevance. Then, the right hemisphere is responsible for initiating strategic control of the attention while left hemisphere uses the information to initiate certain stimulus and keep the sequence.

In the prefrontal area, all the information are evaluated, and decision making is made based on the state of the feeling. If the decision is to perform certain activities, the brain, then will initiate planning to execute the action. By the force of implicit knowledge, the action will be executed. This processes will be repeated over and over to controlling communication as being expected. In aphasic and dysphasic patient, the action is frequently out of control because various options of phonemes cannot be processed in the prefrontal cortex. During the process in the brain, selective attention is focused on its task. The attention and memory have important role in entire processes, and their capacities have to be fitted with the task directed by the brain.

Sastra, et al. [6] has developed the Prins's method by analyzing linguistic data of the patients and developed speech therapy method to improve communication skill of the patients 
by focusing on phonological, lexical, syntactic, and semantic competence. The model is a reflection of a framework based on linguistic analysis toward patients' utterances. Having related to the theory above, a diagram is designed to describe the structural relation of linguistic competence of the patients based on the analysis of the data. The development of functional speech therapy concerning linguistic competences is elaborated in the form of scheme and text.

Development of a theoretical model of current speech therapy method covers the following steps: They are (1) functional therapy is based on phonological, lexical, and semantic impairment; (2) activity therapy; and (3) accomplishments of therapeutic effect. The steps will be developed through verbal and nonverbal communication treatment with the following subjects: 1) retelling story; 2) reading and writing information; 3) providing visual characteristic; 4) expressive prosody; 5) receptive prosody; 6) delayed storied, and 7) describing the picture. The steps of the therapy model and treatment of communication skills are reflected in the below scheme:

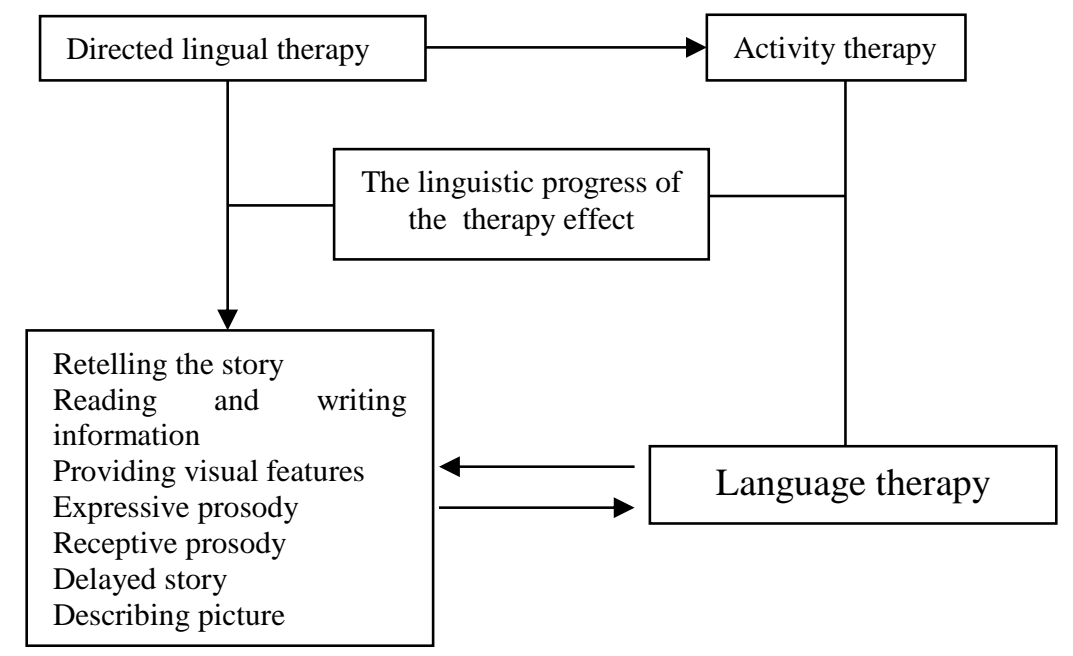

Fig. 1. Therapy model and treatment of communication skills

The treatment of verbal and nonverbal language therapy in communication has based the steps above. Scoring is based on a score of the unity of the story which is performed by the patient using summarized index (SI).

$$
\text { SI }=\frac{\text { Total words }}{\text { The correct unit of information }} \text { X } 100 \%
$$

Summarised index will affect linguistic error produced by the patients. Based on the summarised index and linguistic error of aphasic and dysphasic patient a model of speech therapy is designed which applies to aphasic and dysphasic patients. The model is tested to figure out the improvement of the communication skills of the patient with the audiences.

The procedure of therapy is based on vowel and consonant change. Both vowel and consonant move to the centre of understanding through airwave which has certain intensity and frequency to become a meaningful sound (based on the concept). The sound is divided into 
segmental and suprasegmental. Segmental sound can be seen from the division of sentence to phoneme while supra-segmental cannot. Segmental sound can be evaluated from the character of sound and its point of articulation, while the suprasegmental sound is identified through the intended meaning and the feeling of the speaker. Vocal is a sound produced by the modification of air circulation in the glottal area (with certain intensity and frequency) directly without any hindrance.

The variation of the vocal is due to the change of form and size of the resonator and the effect of tongue position based on the three groups of vocal sounds. They are (1) high, front and non round /i/, /e/, /e/; (2) low vocal, back and throat; /a/, /a/; and (3) high vocal, back and round: $\mathrm{u} /, / \mathrm{o} /, / \mathrm{o} /$. A consonant is a sound produced with or without phonation in which the air flowing in the glottal area is modified by hindrance, the muscles of articulation organs in or pharynx area. The contractions of these articulation muscles will change to be slow, stopping and exploding the air flowing in the glottal area. The change of vocal and consonant sound in aphasia patients becomes the basis of language training toward the patient.

Based on the consideration above, this research is focused on the problems below: (1) how is the scheme of language therapy to treat aphasia patient? (2) How far does emotion effect the lexical knowledge and semantic of aphasia patient? Moreover, (3) how is the achievement of LTM toward speaking disorder of aphasia patient? The problems above are formulated in a framework to improve the language ability of the aphasic patient and to provide the aphasic patient with the ability to communicate with a normal person through LTM.

\section{Method}

Generally, this research is conducted by some steps, i.e. observation and natural approach, directional conversation, understanding story and picture, verbal behaviour simulation, evaluation to all activities [7] and the application of LTM. These steps are elaborated in method and technique in collecting data, analyzing data, and presenting the result of analysis [8].

The population of the research is verbal utterances of aphasic patients in RS M Djamil Padang. The samples are four aphasic patients who have been observed by the researcher for three months. Moreover, the researcher also conducts another two months extended research to verify therapy application in healing period. These four subjects are patient of RS M Djamil Padang who set got a stroke and show the symptom of aphasia Two of them are hospitalized, and two others are ongoing patients. Their communication impairment is indicated by BDDE (Boston Diagnostic Dysarthria Examination) scale with a range of 2-4. The patients are high school graduate and have lived in Padang for at least for ten years. Two of the four patients are indicated aphasia Broca with the scale of severity 4 of BDAE scale, and after two years of stroke, the level is going down to level 3 BDAE. One patient gets aphasia from the beginning of the stroke attack due to impairment in the central nerve which distracts him from controlling speech organs. The other one gets aphasia with the level of damage 2 of BDDE scale since he got an accident. The utterances of the patients are triggered by evaluating patients' language skills, including direct question and answer, naming object, and retelling a story. The topic of language evaluation consists of daily activities and the history of illness. In naming the object of the test is based on Dharmaperwira-Prins [5] while is a user insulation to Cookie Theft [9]. The data are transcripted and analyzed based on the recording of the patients' utterances. 


\section{Results and Discussion}

\subsection{Therapy Scheme}

The results of a therapeutic scheme in treating Indonesian aphasic patients based on the Language Therapy Model (LTM) can be seen in the following arguments. The development of language therapy is designed to improve the communication skill of aphasic patients. The model is created based on pathology treatment of Hedge [10] which is combined with behavioural therapy model proposed by Sastra, et al. [6]. The following scheme gives guidance to treat aphasic patients by providing structural steps. The families of the patient are getting involved in the treatment from the process of identification through the arranging strategy. The therapy is designed as figure 2 .

The aphasic patient should be examined comprehensively. In other words, aphasic patient as an object of this research should be analyzed by some steps based on the applied cognitive assessment comprehensively which then applied by Sastra, et al. [4]. Those steps are; two-side task -- semantic memory; the relationship of a picture to another -- word fluency; ability in naming -- the memory of recognizing -- things modelling - arithmetic; simple calculation; and multiple choices. Also, the language batteries used in the current research are oral language in the form of words and sentences, written language by the meaning of words and oral paragraph, words repetition, naming object, reading words and words function, dictating and writing pictures. The batteries are used to train the competences of listening verbal expression.

The objective of speech therapy is to provide the patient with functional communication skills due to the assisted patient can communicate in a social situation. The procedures of functional communication toward aphasic patients are: 1) linguistics accuracy based communication, 2) selecting appropriate word, phrase, or sentence for communication, 3) beginning with words or sentences that patient able to produce, 4) adding syllable to modify word and using word to modify phrase, 5) adding words to create sentence, 6) using various form of sentence (active, passive, adjectival and adverbial structure, preposition, pronoun, etc.), 7) using specific stimulus (picture, model, etc.), 8) continuing conversation (asking patient to tell about personal experience or telling a story), 9) designing turn-taking conversation, 10) training patient to design his strategy, 11) designing intra-subject discussion section to provide sharing groups, 12) training family to assist patient producing utterance, observing patient strength, emotional expression to help patients, and to convince patient to communicate and participate in activities either in hospital or home. 


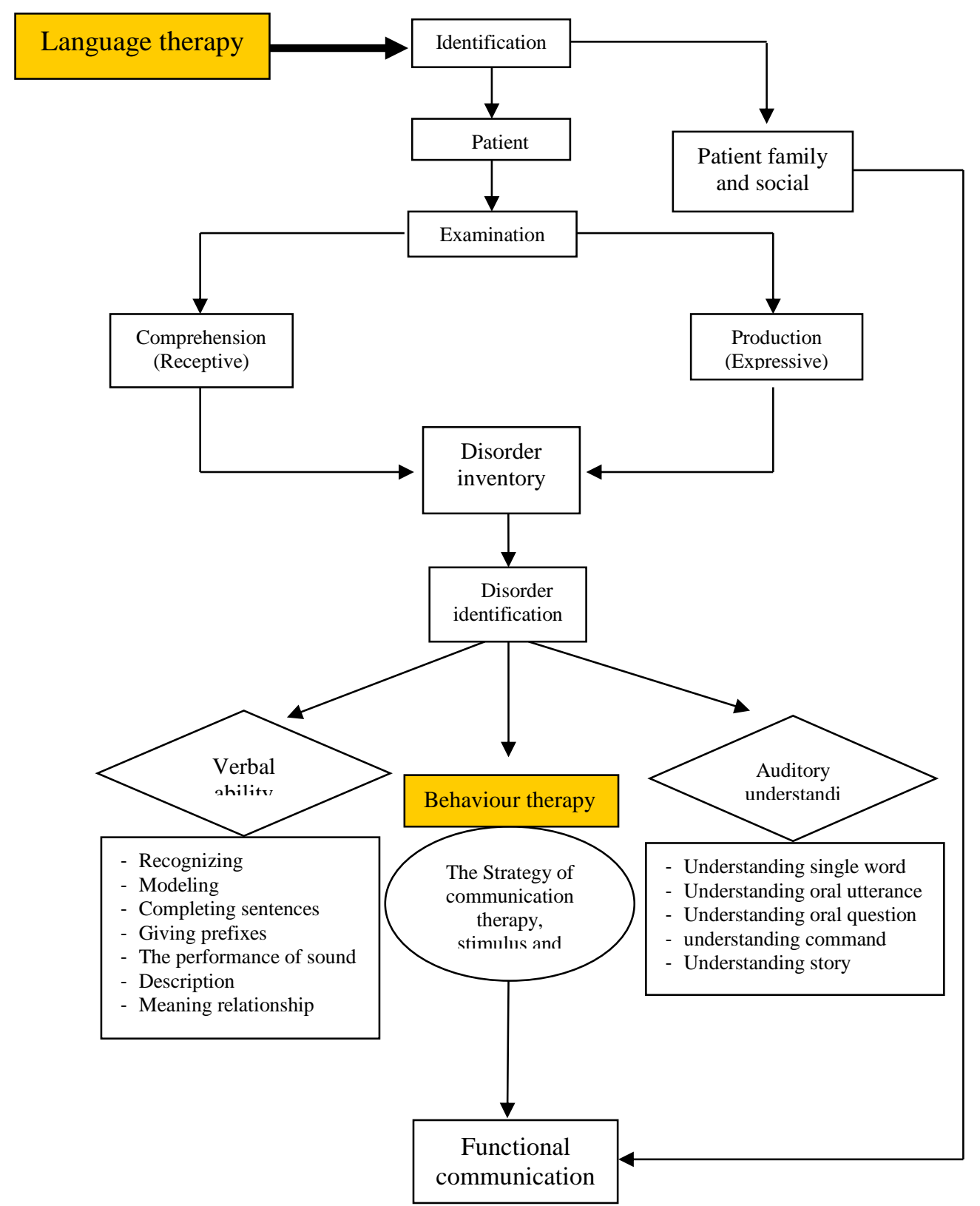

Fig. 2. Behavioural therapy model for Language Impairment 


\subsection{Language Error of Aphasic Patients}

Language error is a reflection of oral competence of the patient in producing language, including phoneme, word, sentence, and context as the audience expected. Aphasic patients are frequently performing various linguistic error, among other switch error, deletion, insertion, and substitution. These errors frequently occur in language and speech disorder of aphasic patients. Many studies have on various disorders, such as dysarthria, cerebral palsy, stutter, and autism, have indicated these linguistic errors. Therefore, it can be inferred that patients with language disorders have a serious problem in phonological encoding, agrammatism, and syntactic structure. It means that aphasic patients have linguistic disorders when doing communication. This is in accordance to Kohn's [11] viewpoint mentioned that when a patient has difficulties in producing phoneme, he tends to omit the phoneme and word in order to produce specific phonetic or syntactic form. This current research shows significant errors in producing language. They are 24:33: 3:8:6. The result can be seen in the following chart:

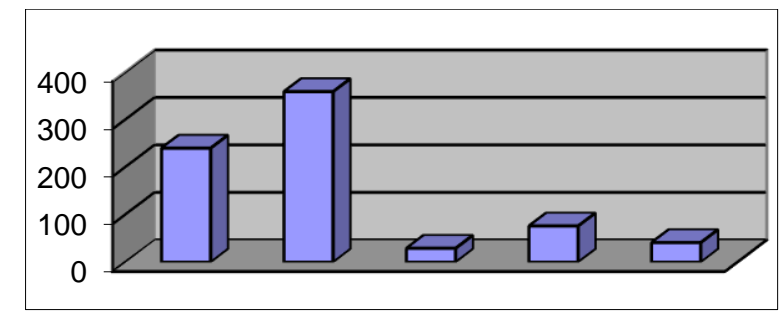

Fig. 3. The language error of aphasia patient

The errors indicate that the aphasic patients frequently sound omission (33\%) and use the first syllable to access intended lexical by minimising the sounds (3\%). Sound replacement (24\%) also occurred due to lexical hop which leads the patients to switch the position of phoneme and syllable. Lexical shortened (6\%) also happened for performing response quickly since the patients are bored to be trained their speech organ repeatedly.

Based on the phonetic aspect of aphasic patients, it indicates that fricative sounds are the most difficult sounds which lead the patients to get error producing sounds. It is a contradiction with a sound revival in dysphasic patients in term of language acquisition. The arguments are relevant to what is expressed by Jakobson [12]. He said that in children, the acquisition stop is the easiest sound to be produced while in an aphasic patient, the stop sound is the most difficult sound. Hence in an aphasic patient, voiced, lateral, aproximum, and fricative are difficult to be re-acquired.

Distinctive features of replacement errors are dominant in an aphasic patient, disposition in distinctive place of articulation occurs approximately $44 \%$, characteristic of the manner of articulation 29\%, and characteristic of distinctive voice $27 \%$. In term of neuroscience, the nervous cell and muscle which keep and control active articulator are greater than the nervous system and muscle controlling glottis position while producing voiced sound. This result seems working to the viewpoint of Crystal [13], Obler and Gjerlow [14], that the cranial nervous system functioning keeps and control the active articulator consists of cell $\mathrm{V}$ which manages muscle of lower jaw, cell VII for face muscle, cell IX for back tongue muscle and throat, cell X for muscle of soft palate, ovular, pharynx, and larynx. Cell XII manages tongue muscle while controlling glottis cell $\mathrm{X}$ or vagus cranial muscle used. 
Furthermore, the peripheral nervous system which is involved in the manner of articulation is more complicated than in sounds production. Regarding distinctive feature of articulation manner, segmental sounds are produced by controlling lips muscle, ovular, tongue, and lower jaw. Those muscles are controlled by the different cranial nervous system.

\subsection{The Effect of Emotion toward Lexical and Semantic}

Feeling and emotion state have a significant role to lexical and semantic competence of the patient, either the primary feeling (innate) or secondary feeling. All of the mental pictures are related to a certain feeling while emotional state triggers chemical response which will affect the cognitive process. The meaning of certain feeling is closely related to experience. Therefore, by using pictures patients can retrieve a certain emotional state due to the comprehensive lexical concept. Among the lexical data used in the current research, the result shows an equal ratio between emotion and knowledge, while lexical semantic competence is quite low. It indicates that emotional state is closely related to lexical knowledge even though the lexical comprehension is quite low. The level of comprehension can be improved by exposing linguistic therapy toward the patients. The ratios of these aspects are $45 \%$ for lexical knowledge, $18 \%$ for lexical semantic, and $38 \%$ for lexical emotion.

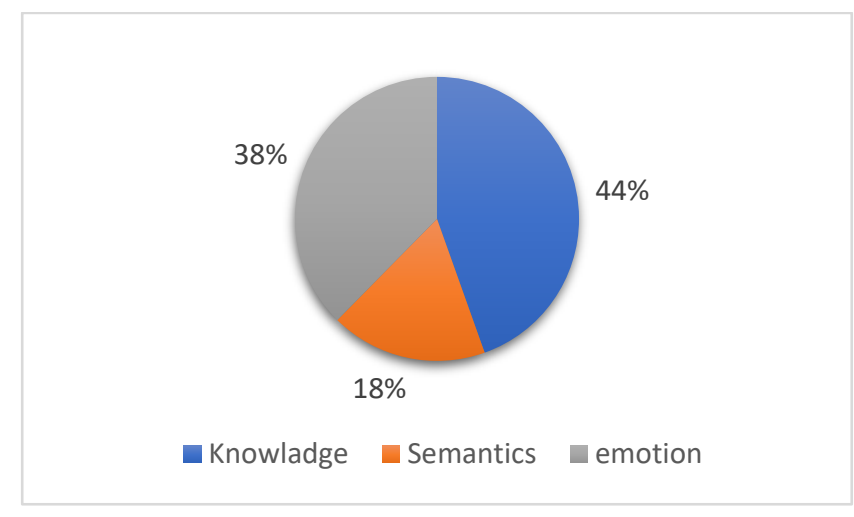

Fig. 4. Ratio of lexical knowledge, semantic and emotion

The following utterance is aphasic patient's utterance which indicates the effect of lexical emotion toward lexical knowledge and semantic:

$\mathrm{P} \quad$ : Bisa Bapak ceritakan gambar ini? (Can you tell us about this picture?)

SP3 : "Oo...i..ni...am pung abo...ti...gi..., ki...lo duu wo luh nik....ba ba..to...to? a a ri...pa? ka...c...ko, jin...a? mmh, kaka...d mmaa lam pa sam mrah....., do sasasa...jo lau...di am pu...s tu. A...pa? yooo nang...aja...., tu? ma mas wa so pa?, aaahha.....ha...pi ni..ni...ai...pa? pa ppa mulah. $O$ yoooo, mpusko......aad...bushhh ta, kaanncici...ng kaakkancca...., mpai...mmti mmma mm s.aw...., iiyo, sadoh pa? Ye? Uuulang nnik buush tu, ssuudah tu ssaammpai sabaru sa laii. Di ja ko cccokk llla mmmh, ssiiikko ng ng ngan mpa, taaga? Pa? Kikini bok pak...” 
/ini kampus ambo, tinggi ko, kiro-kiro 20 minik baoto, tiok hari Apak kasiko, rajin apak mah, kadang malam sampai di rumah, ado se kalau alah di kampus tu. Apak maaja iyo sanang, mahasiswa takui jo apak mah, hahaha, nilai lai pamurah apak. Oyo, kampus ko ado bus kota kancang-kancang mah, sampai mati mahasiswa, iyo sadiah apak maliek urang naiak bus kota tu, sudah tu sampai pasa baru se lai. Di jalan ko apak acok lalu mah, aa iko kampus apak a, ruangan apak Siko ha...iyo...taragak apak baoklah apak kiniko/

'Oo this one... this is my campus, the high, approximately 20 minutes by car, I come here every day, even I reach home at night, there is always work to do on the campus. I love teaching, the students are afraid of me, but I gave them good marks. In this campus, the city bus drives so fast, even killed students, I am so sad seeing people in the bus, but now it drives through to Pasar Baru only. I often pass this road, yes this is my campus, this is my room, yes here... I want to go there now, take me there, will you?'

The data above shows that aphasic patient has lexical knowledge about the campus. Even though the researcher asked the patients with Indonesian language but the patient was able to identify the speaker's intention (patient does not bear receptive disorder), that is to describe the picture. The picture is aimed at seeking patient's emotion and lexical comprehension toward lexical 'campus' based on his experience. The patient is led to figuring out the lexical concept of 'campus' which distracts him to describe the whole picture clearly. The picture is the campus map. When the PS points out the certain location in the map, the patient can retrieve lexical 'direction'. The patient cannot produce the word 'campus' and 'campus bus' correctly which are mentioned in the picture. It indicates that the patient has emotional experience toward the picture which leads him to evoke several lexicons about his experience.

\subsection{The Achievement of Language Therapy Method}

Communication with the aphasic patient during the recovery period as partial therapy is not only focusing on linguistic aspect but also involving audio, visual, and tactical approach. The point of view correlated to the behavioural therapy method employs an assessment method and to speech therapy model which are disclosed by Sastra and Hedge. In addition, the procedures of the method are described as follows: (1) information will be sense through audio, visual, and tactical and drives to posterior of the brain, (2) conscious processing runs into the cortical level. The flows of the stimulus are integrated. Semantic knowledge and emotional meaning are defined, (3) in cortical level memory processing are integrated into various choices. The patient will compare the information with semantic knowledge, and (4) certain action will be considered in pre-frontal cortex and decisions are made. Initiation will be an impulse to execute the selective process from the lexical index in the brain.

Behavioural therapy method (including feeling and emotion) is important to be conducted in treating the aphasic patient, especially during the recovery period. Expressive treatment toward aphasic patient employs speech therapy method focusing on identification strategy. This strategy is used to stimulate and to help the patient to identify and name the object.

The current research conducts several steps toward aphasic patient by providing 50 speech acts as mentioned below: 1) frequently used words (70\%), 2) naming manipulated objects $(22 \%), 3)$ realistic rather than abstract picture (46\%), 4) phonemic assist (37\%), 5) visual 
stimulus and continual sounds (67\%), and 6) stimulus employed toward the patients is modelled by asking certain topic, practising the response, asking the patient to repeat the process, and asking the patient to repeat correctly. The modelling employed toward the patient improves patient's skill more than $86 \%$.

The other stimulus is to sum correct information by employing the following process: 1) sentence completion ('you write with a....; 47\%), 2) initial sound as cues ('you write with a...? the word starts with a p... '; 33\%), 3) syllables as cues ('this is a spoo...'; 72\%), 4) silent phonetic gesture as cues (this is a .....'silent articulation of $/ \mathrm{p} / ; 87$ ), 5) description as cues ('this is a round object that you roll and kick. What do you call it?'; 84\%), 6) demonstration of action as cues ('what is this? You use this to write -demonstrate writing'; 80\%), 7) function demonstration ('tell me what you use this for and then tell me its name'; 74\%), 8) pointing picture (present a book and asked the patient 'what is it?'; 75\%), and 9) using semantic relation, such as synonym, antonym, and hyponym: 64\%).

After having treatment with behavioural therapy method and speech therapy toward aphasic patients for three months, two hours every two days, show the improvement of phonological and lexical accuracy. At the last month of treatment, the accuracy of meaning can be identified as its intention in certain speech act. This achievement proves that the communication skills of the patient are improved. Among 50 speech acts almost $90 \%$ show progress in articulation and words accuracy. The index of achievement chart is formulated by phonological, lexical, and semantic error, as demonstrated below:

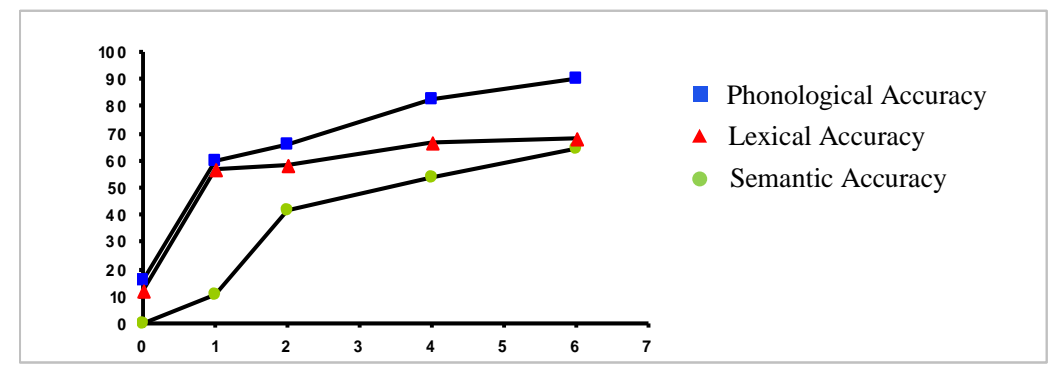

Fig. 5. The Achievement of pronunciation, lexical and semantic accuracy

The chart above shows progressive achievement of implementation of behavioural therapy method toward the aphasic patients. Significant change happens at first and second week due to sense exposing and emotional intimacy toward the patients. Then, from the second week until the sixth week, the chart shows stable progress in articulation, knowledge improvement, lexical choices, understanding repeated speech act, and understanding the picture. Repetition is employed due to internalised phoneme and lexicon both for knowledge and comprehension.

Understanding of lexical concept and articulation accuracy are increased at posttherapy. It can be inferred from speech analyzer of patients' utterances. For instance, the lexical concept of 'campus bus' is showed by the following pictures: 

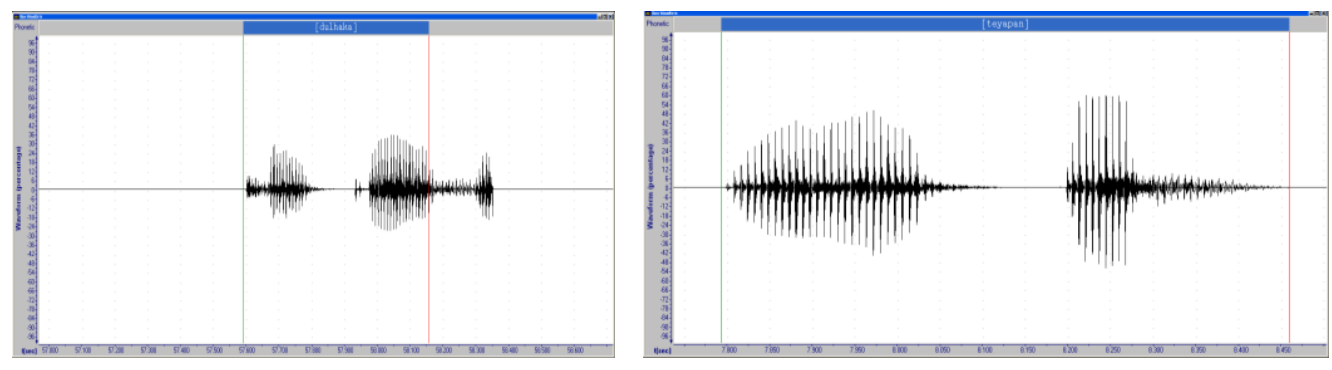

Fig. 6. The result of Post-Therapy using Behavioral Therapy Method

The result of speech analyser for both pre-therapy and post-therapy indicates the progress in lexical articulation. The difference is significant for both vowel and consonant in every word and syllable. Moreover, the space between the wave and the height of the wave also shows stable utterance.

\section{Conclusion}

The research toward the aphasic patient in adult age shows that language disorder in aphasic patient deals with impairment of nerves coordination which manages speaking muscles function. This disorder has a scale of severity depending on the impairment of language function in the brain. Aphasia can be caused by a stroke which affects the communication skill of the patient.

Various linguistic symptoms are reflected from verbal behaviour of the aphasic patient. The highest number of error is verbal deletion (33\%). The influence of emotion toward lexical knowledge and lexical emotion is equal (48\% and 38\%), while comprehension of lexical meaning is quite lower (18\%) than lexical knowledge and lexical emotion.

Due to the improvement of communicative skills of an aphasic patient, behavioural therapy method and speech therapy can be applied toward the patient by focusing on enhancing expressive skill through stimulus. The highest score for stimulus is sound modelling (87\%) while the lowest is an initial sound cue (33\%). The application of behavioural therapy method and speech therapy shows the significant result which can be inferred from the improvement of patient's verbal skills. The use of various stimulation shows progress in linguistic accuracy of the aphasic patients, including phonology, lexicon, and semantic.

\section{References}

[1] Kusumoputro, Sidiarto. (1993). Afasia: Gangguan Berbahasa. Jakarta: Balai Penerbit FKUI.

[2] Kusumoputro, Sidiarto. (1981). "Bahasa dan Saraf Manusia" dalam Pengembangan Ilmu Bahasa dan Pembinaan Bangsa, ed. Harimurti Kridalaksana, 256 - 267. Ende: Nusa Indah.

[3] Alajuoanine, A. Ombredane \& Marguerite Durand. (1939). Le Syndrome de Desintegration Phonetique dans Iaphasie. Andre Ombredane at Theopile Alajouanine. Paris: Masson. 
[4] Sastra, Gusdi, et al. 2013_. "Penyusunan Model Terapi Wicara untuk Berbagai Jenis Gangguan Berbahasa dan Berbicara". Laporan Penelitian. Padang: Universitas Andalas.

[5] Dharmaperwira- Prins, R. (2004). Gangguan-gangguan Komunikasi. Jakarta: Djambatan

[6] Sastra, Gusdi. Et al. (2012). "Penerapan Model Terapi Linguistik Penderita Disartria. Laporan Penelitian. Padang: Universitas Andalas.

[7] Nunan, David. (1992). Research Methods in Language Learning. Cambridge: Cambridge University Press.

[8] Sudaryanto, (1993). Metode dan Aneka Teknik Analisis Bahasa: Pengantar Penelitian Wahana Kebudayaan Secara Linguistis. Yogyakarta: Gadjah Mada University Press.

[9] Goodglass and Kaplan. (1995). Normal Speech \& Language Development. http://www. Pedsinreviewappluublications. org.

[10] Hedge. (2001). Pocket Guide to Assessment in Speech-Language Pathology. (Second Edition).

[11] Kohn, Susan E. (1993). "Segmental Disorders in Aphasia" dalam Linguistics Disorders and Pathologies, ed. Gerhard Blanken, Jurgen Dittmann, Hannelore Grimm, John C.

[12] Jakobson, Roman. (1971). Studies on Child Language and Aphasia. Janua Linguarum Series Minor. The Hague: Mouton.

[13] Crystal, David. (1980). A First Dictionary of Linguistics and Phonetics. Great Britain: Cambridge Universtiy Press.

[14] Obler, K., Oraine dan Kris Gjerlow. (2000). Language and the Brain. Cambrigde: Cambridge University Press 